\section{Perbandingan Total Mikroba Kombucha dengan Variasi Jenis Teh dan Lama Fermentasi}

\author{
Azrini Khaerah \\ Halijah \\ Nurhilmi Nawir
}

\begin{abstract}
Abstrak. Kombucha merupakan minuman hasil fermentasi cairan teh dan gula. Fermentasi dilakukan oleh konsorsia bakteri dan khamir yang melakukan simbiosis kooperasi menghasilkan kombucha yang mengandung senyawa kimia yang berkhasiat baik bagi tubuh. Proses fermentasi dapat merubah karakter fisik dari cairan teh, seperti rasa, warna dan baunya. Selama masa fermentasi, bakteri dan khamir tersebut juga mengalami perubahan. Pada penelitian ini digunakan 4 jenis teh yaitu teh hitam, teh hijau, teh oolong dan teh putih. Hasil penelitian ditemukan bahwa jenis teh substrat serta lama fermentasi dapat mempengaruhi total koloni dan total sel bakteri dan khamir yang terdapat di dalam kombucha. Pada pengamatan total sel bakteri dan khamir, kombucha teh putih dan teh hitam mengalami penurunan sementara pada kombucha teh oolong dan teh hijau mengalami peningkatan.

Kata kunci. kombucha, fermentasi, total mikroba, SCOBY, hemasitometer
\end{abstract}

\section{Pendahuluan}

Teh Camellia sinensis merupakan salah satu tanaman perkebunan yang banyak di tanam di Indonesia. Umumnya teh ini dikonsumsi dengan cara diseduh bagian daunnya kemudian diminum. Sebelum dikonsumsi, teh melalui beberapa proses pengolahan, diantaranya pemetikan pucuk, pelayuan, penggulungan, pengeringan, bahkan sampai tahap oksidasi enzimatis (Rohdiana, 2015). Selain itu, teh juga banyak dimanfaatkan untuk pembuatan bahan kosmetik, pasta gigi, obat penurun berat badan, dan sebagainya (Towaha, 2013). Pada dasarnya, teh mengandung berbagai senyawa kimia yang bermanfaat untuk tubuh. Beberapa senyawa yang dikandungnya diantaranya fenol yang memberikan efek antioksidan, berbagai asam organik, beberapa mineral dan enzim. Berdasarkan proses yang dilalui oleh teh, setidaknya ada 4 jenis teh yang komersial dapat ditemukan di pasaran, yaitu teh hijau, teh hitam, teh oolong dan teh putih. Semakin banyak proses yang dilalui, maka semakin sedikit fenol yang dikandungnya. Hasil penelitian yang dilakukan oleh Lelita, dkk (2018) menemukan bahwa dari keempat jenis teh tersebut, kapasitas antioksidan penangkapan radikal bebas DPPH pada konsentrasi 1000 ppm, 1250 ppm dan 1500 ppm, teh putih memiliki kapasitas yang paling tinggi, kemudian diikuti oleh teh oolong, teh hiijau dan teh hitam. Dengan kandungan yang dimiliki tersebut, teh

\section{BIONATURE}

\author{
p-ISSN 1411 - 4720 \\ e-ISSN 2654 - 5160
}

Abstract. Kombucha is a fermented beverage made from tea and sugar. This fermentation is a work of bacteria and yeast consorsia that make a powerful symbiosis cooperation resulting

kombucha with quality chemically increased. This kombucha is a healthful beverage for its consumer. Fermentation process can change the tea phisically, such as its taste, colour and flavor.

During the fermentation period, the total cell of bacteria and yeast also change. In this research, kombucha is made from 4 different tea, such as black tea, green tea, oolong tea and white tea.

As a result, found that the tea as a

substrate and also the fermentation period affect the total of colony and cell of bacteria and yeast. In white tea and black tea kombucha perform decreased of total cell bacteria and yeast by the fermentation period, while in green tea and oolong tea kombucha increased.

Keywords. kombucha, fermentation, total microbes, SCOBY, haemacytometer

Azrini Khaerah

Universitas Muhammadiyah Bulukumba Indonesia

Halijah

Universitas Muhammadiyah Bulukumba Indonesia

Nurhilmi Nawir Universitas Muhammadiyah Bulukumba Indonesia 
sangat bersyarat untuk dijadikan bahan dasar pembuatan kombucha.

Kombucha adalah minuman kesehatan yang dibuat dengan bahan dasar cairan yang dibuat dari berbagai dedaunan yang memiliki senyawa fenol tinggi. Dedaunan yang dapat digunakan seperti daun teh, kopi, sirsak dan lainnya (Suhardini dan Zubaidah, 2016). Dengan adanya senyawa yang berada pada bahan dasar tersebut, kombucha mengandung berbagai senyawa kimia yang sangat baik bagi tubuh. Dari proses fermentasi cairan tehyang dilakukan oleh konsorsia mikroba terdiri atas bakteri dan khamir (SCOBY) dihasilkan minuman kombucha yang emnagndung etanol, berbagai asam organik seperti asam sitrat, asam asetat, berbagai vitamin dan mineral yang tentunya dapat meningkatkan kualitas kandungan senyawa organik teh (Tran, et al., 2020). Dengan berbagai kandungan yang dimilikiKombucha memiliki manfaat yang sangat baik bagi tubuh konsumennya, seperti memperbaiki mikroflora usus, melancarkan metabolisme, meningkatkan ketahanan tubuh dan menurunkan tekanan darah (Suhardini dan Zubaidah, 2016). Bahkan, Sreeramulu, et al. (2000) menjelaskan bahwa minuman kombucha dilaporkan mampu membantu mengatasi berbagai penyakit seperti indigesti, konstipasi, artitis, psoriasis, hipertensi dan penyakit metabolisme lainnya.

Mikroba yang berperan di dalam proses fermentasi kombucha merupakan gabungan dari bakteri dan khamir. Kedua kelompok mikroba ini melakukan proses kerja simultan yang saling mendukung. Khamir akan mengkonversi sukrosa menjadi glukosa dan fruktosa. Selanjutnya bakteri yang dalam hal ini bakteri asam asetat akan mengoksidasi glukosa menjadi berbagai senyawa kimia melalui metabolisme oksidatif. Sebagai senyawa sampingan, dari hasil fermentasi awal ini dihasilkan eanol. Selain itu, bakteri menghasilkan pula serat selulosa yang selanjutnya akan berada di permukaan cairan dan dikenal secara spesifik sebagai SCOBY (Tran, et al., 2020).

Kombucha dibuat dengan melalui tahap fermentasi yang umumnya menggunakan masa fermentasi 14 hari. Lama fermentasi ini dapat disesuaikan dengan keinginan serta rasa yang dikehndaki oleh konsumen. Masa fermentasi maksimal yang dikonfirmasi baik bagi kesehatan adalah 21 hari. Adapaun beberapa penelitian melakukan uji coba variasi lama fermentasi untuk melihat dinamika senyawa kimia dan jumlah mikrobanya. Jayabalan, et al. (2014) menemukan bahwa semakin lama fermentasi, senyawa kimia akan meningkat begitu pula jumlah mikrobanya. Akan tetapi pada masa fermentasi tertentu, fermentasi akan menurun dan mengakibatkan penghasilan senyawa kimia akan menurun pula. Penentuan lama fermentasi ini didasarkan pada jenis substrat, tempat fermentasi dan sumber inokulumnya.

\section{Metode Penelitian}

\section{Preparasi teh}

Pada peneltian ini dilakukan pembuatan kombucha dengan 4 jenis teh sebagai substrat, yaitu teh hijau, teh hitam, teh oolong dan teh putih.pembuatan kombucha dilakukan dengan merebus air sebanyak 3 liter. Setelah mendidih, ditambahan teh sebanyak 5 kantong teh kemudian diaduk hingga homogen. Selanjutnya ditambahakn gula sebanyak 231 gram dan diaduk rata. Kemudian cairan tersebut dibiarkan hingga mencapai suhu ruangan. Selanjutnya dipindahkan pada toples kaca yang telah disterilkan. Selanjutnya diberikan starter kombucha sebanyak 10\% dari jumlah sampel. Kemudian diaduk dan kemudian ditambahkan SCOBY. Setelah itu, mulut wadah ditutup dengan 2 lapis tissue. Selanjutnya dilakukan proses fermentasi dengan 2 variasi waktu, yaitu 7 hari dan 14 hari.

\section{Perhitungan Jumlah Koloni Mikroba}

Perhitungan jumlah koloni dilakukan dengan menggunakan media LBA dan TSA. Kedua media tersebut dapat mendukung pertumbuhan bakteri dan khamir. Setiap 16 sampel kombucha yang dibuat diinokulasikan ke media LBA dan TSA dengan teknik spread plate. Teknik ini digunakan karena diketahui bakteri dan khamir yang berperan dalam proses fermentasi 
kombucha bersofat aerob. Kemudian sampel diratakan dengan menggunakan hockey stick. Setiap sampel diinokulasikan ke dalam media dengan dua kali pengulangan. Selanjutnya diinkubasi pada suhu $37^{\circ} \mathrm{C}$ selama 24 jam. Setelah proses inkubasi, dilakukan perhitungan koloni yang tampak.

\section{Perhitungan Jumlah Sel Mikroba}

Perhitungan jumlah sel mikroba dilakukan dengan teknik hitung langsung menggunakan hemasitometer. Setiap sampel dilakukan homogenisasi sebelum pembuatan preparat. Setiap $1 \mathrm{ml}$ sampel diletakkan di atas plat pengamatan kemudian dihitung jumlah sel mikroba yang nampak. Selanjutnya dihitung jumlah sel bakteri dan khamir yang nampak. Perhitungan total sel bakteri dan khamir dilakukan di Laboratorium Kesehatan Ikan BBAP Takalar.

\section{Hasil dan Pembahasan}

Tahapan penelitian yang dilakukan dimulai dengan membuat kombucha dengan bahan dasar 4 jenis teh yang berbeda (teh hijau, teh hitam, teh putih dan teh oolong) dengan 2 jenis lama waktu fermentasi ( 7 dan 14 hari). Adapun pengujian yang dilakukan adalah perhitungan total koloni mikroba dengan metode plating dan perhitungan sel mikroba (yeast dan bakteri) dengan metode hitung langsung menggunakan haemacytometer.

\section{Fermentasi Teh}

Teh kombucha adalah minuman segar hasil fermentasi dari teh manis dengan bantuan yeast dan bakteri pembentuk asam. Kultur kombucha yang biasa dikenal dengan sebutan SCOBY (symbiotic culture of bacteria and yeast) mengandung berbagai jenis mikroorganisme. Adapun mikroorganisme di dalamnya terdiri dari bakteri Acetobacter xylinum, Acetobacter aceti, Acetobacter pasteurianus, Lactobacillus sp, Pediococcus sp, Gluconacetobacter dan Gluconobacter. Kemudian juga terdapat beberapa yeast yang terdiri dari Brettanamyces bruxellensis, Brettanamyces intermedius, Candida fomata, Mycoderma, Mycotorula, Saccharomyces cerevisiae, Schippzosaccharomyces, Torula, Torulaspora delbrueckii, Torulopsis, Zygosaccharomyces bailii dan Zygosaccharomyces rouxii (Crum dan Alex, 2016).

Keberadaan mikroorganisme tersebut memiliki peranan yang sangat penting di dalam proses fermentasi kombucha. Kumpulan yeast dan bakteri tersebut berbentuk lembaran menyerupai kulit. SCOBY merupakan gabungan selulosa yang berbentuk seperti nata yang dapat terbentuk di dasar atau di permukaan larutan teh hasil fermentasi dan secara cepat memperbanyak diri (Crum dan Alex, 2016).

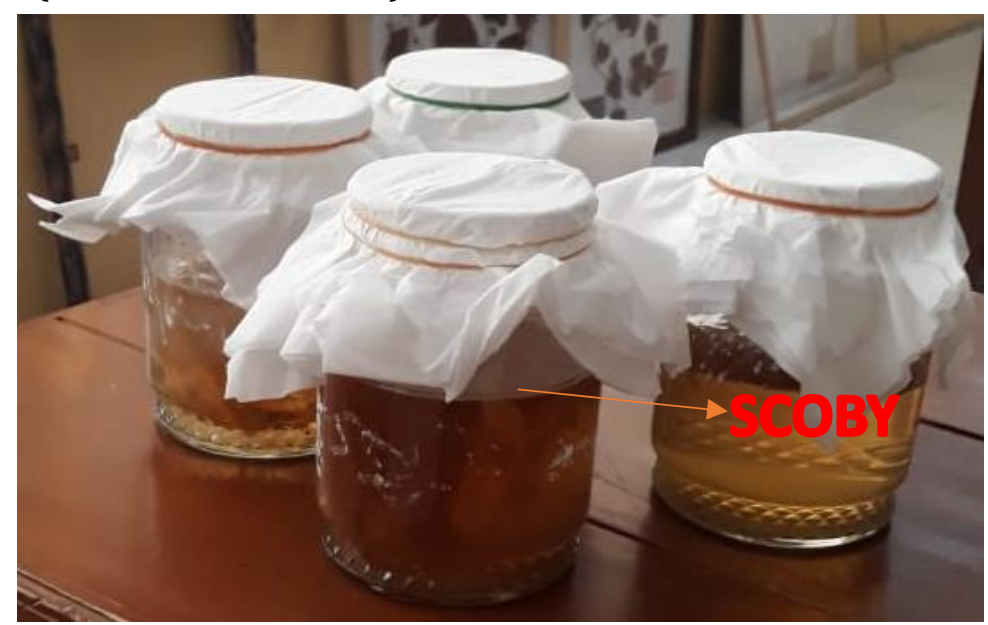

Gambar 1. Kombucha dan SCOBY 
Secara umum, teh yang biasanya digunakan sebagai medium pertumbuhan SCOBY adalah teh hijau dan teh hitam. Hal ini dikarenakan kedua jenis teh tersebut memiliki sumber nitrogen yang tinggi yakni derivat purin, kafein dan teofilin. Senyawa tersebut merupakan senyawa yang sangat penting dalam pertumbuhan dan reproduksi sel SCOBY (Essawet, et al. 2015).

Karakter fisik awal yang teramati dari proses fermentasi oleh mikroba ini adalah perubahan warna dari cairan teh. Warna cairan teh yang pekat kemudian perlahan memudar seiring waktu fermentasi. Hal ini terjadi karena proses degradasi warna yang dilakukan oleh mikroba fermenter akibat penggunaan total soluble solid yang dikandung oeh cairan teh (Nainggolan, 2009). Akibatnya, semakin lama fermentasi, semakin bening cairan kombucha yang dihasilkan. Warna SCOBY yang dihasilkan dari setiap jenis teh pun berbeda. Hal ini sebagai akibat dari warna dasar yang dimiliki oleh cairan teh sebagai substrat pertumbuhan mikroba.

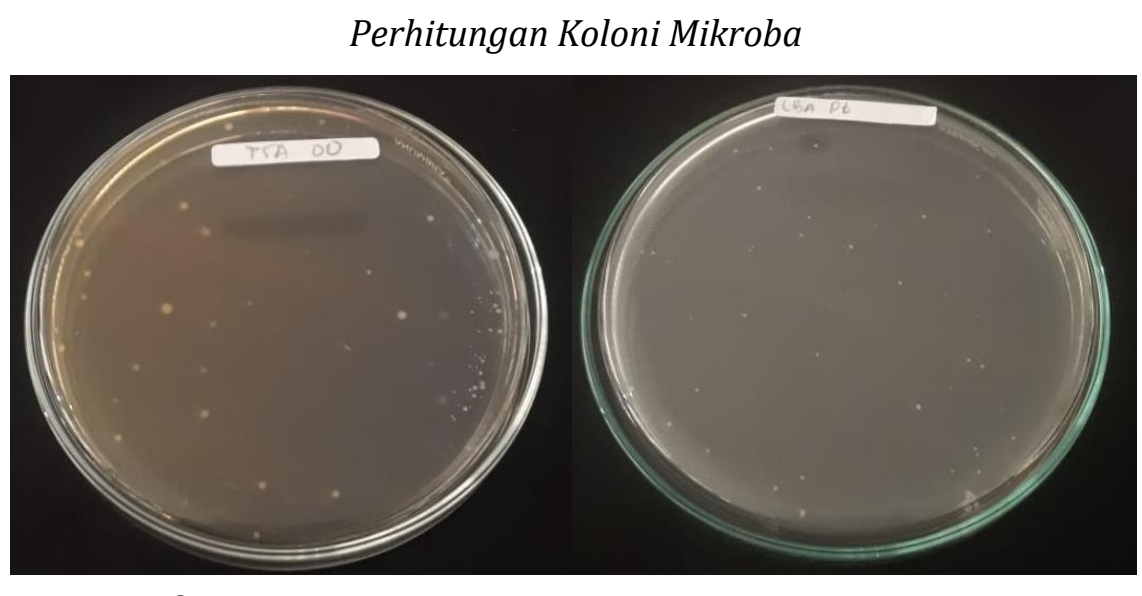

A

B

Gambar 2. Pertumbuhan mikroba pada media A. TSA, B. LBA

Perhitungan total koloni dilakukan dengan menggunakan media padat dalam cawan petri. Media yang digunakan ada 2 macam, yaitu LBA dan TSA. Pemilihan media tersebut didasarkan pada jenis mikroba yang hidup sebagai fermenter di dalam kombucha yakni bakteri dan yeast. Sedangkan untuk jenis bakteri dan yeast yang hidup didalamnya akan berbeda untuk setiap jenis kombucha. Jayabalan, et al (2014) mengatakan bahwa kita tidak dapat menyimpulkan jenis bakteri ataupun yeast yang hidup di dalam satu sistem fermentasi kombucha. Hal tersebut terjadi karena jenis bakteri dan yeast tersebut tergantung dari sumber inokulum untuk fermetasi teh. Jenis mikroba yang berhasil dikonfirmasi keberadaanya adalah hasil penelitian Hasseltine di tahun 1965 yang berhasil mengisolasi Acetobacter sp. dan 2 jenis yeast lainnya dan kemudian menggunakannya untuk pembuatan kombucha lebih lanjut.

Tabel 1. Perhitungan jumlah koloni pada kombucha dengan fermentasi 7 hari

\begin{tabular}{|c|c|c|c|c|c|}
\hline \multirow{2}{*}{ No } & \multirow{2}{*}{ Sampel } & \multirow{2}{*}{ Media } & \multicolumn{2}{|c|}{ Ulangan } & \multirow{2}{*}{ Rata-Rata } \\
\hline & & & 1 & 2 & \\
\hline \multirow{2}{*}{1} & \multirow{2}{*}{ Teh Putih } & LBA & 145 & 282 & 213,5 \\
\hline & & TSA & 185 & 233 & 209 \\
\hline \multirow{2}{*}{2} & \multirow{2}{*}{ Teh Hitam } & LBA & 12 & 30 & 21 \\
\hline & & TSA & 43 & 457 & 250 \\
\hline \multirow{2}{*}{3} & \multirow{2}{*}{ Teh Hijau } & LBA & 379 & 673 & 526 \\
\hline & & TSA & 216 & 265 & 240,5 \\
\hline \multirow[b]{2}{*}{4} & \multirow{2}{*}{ Teh Oolong } & LBA & 254 & 173 & 213,5 \\
\hline & & TSA & 92 & 78 & 85 \\
\hline
\end{tabular}


Tabel 2. Perhitungan jumlah koloni pada kombucha dengan fermentasi 14 hari

\begin{tabular}{|c|c|c|c|c|c|}
\hline \multirow{2}{*}{ No } & \multirow{2}{*}{ Sampel } & \multirow{2}{*}{ Media } & \multicolumn{2}{|c|}{ Ulangan } & \multirow{2}{*}{ Rata-rata } \\
\hline & & & 1 & 2 & \\
\hline \multirow{2}{*}{1} & \multirow{2}{*}{ Teh Putih } & LBA & 222 & 145 & 183,5 \\
\hline & & TSA & 173 & 210 & 191,5 \\
\hline \multirow{2}{*}{2} & \multirow{2}{*}{ Teh Hitam } & LBA & 19 & 45 & 32 \\
\hline & & TSA & 40 & 72 & 56 \\
\hline \multirow{2}{*}{3} & \multirow{2}{*}{ Teh Hijau } & LBA & 71 & 20 & 45,5 \\
\hline & & TSA & 103 & 67 & 85 \\
\hline \multirow{2}{*}{4} & \multirow{2}{*}{ Teh Oolong } & LBA & 299 & 195 & 247 \\
\hline & & TSA & 210 & 150 & 180 \\
\hline
\end{tabular}

Data pada Tabel menunjukkan bahwa beberapa jenis kombucha mengalami peningkatan jumlah koloni sementara yang lainnya mengalami penurunan. Hal ini dipengaruhi oleh kondisi dan dinamika di dalam proses fermentasi kombucha. Chakravorty (2016) menyatakan bahwa proses dan bagian biokimiawi akan mengalami perubahan seiring dengan proses fermentasi, termasuk pula pada jumlah koloni mikroba. Penigkatan maupun pengurangan jumlah koloni ini tidak menentukan perubahan jumlah sel mikroba di dalam kombucha. Adapun hasil perhitungan jumlah sel bakteri dan yeast dapat dilihat pada tabel selanjutnya. Perhitungan sel ini dilakukan untuk melihat tren pertumbuhan sel mikroba seiring dengan lama waktu fermentasi berdasarkan substrat yang digunakan.

Untuk melihat perubahan total koloni yang terjadi, data pad atabel disajikan dalam bentuk diagram batang dibawah ini. Pada diagram terlihat bahwa lama fermentasi sangat mempengaruhi jumlah koloni yang tumbuh pada media. Pada kombucha yang dibuat dengan teh putih terlihat bahwa semakin lama fermentasi, jumlah koloni mikroba semakin sedikit, meskipun jumlah penurunannya tidak begiru signifikan. Pada kombucha teh hitam, hasil perubahan terpantau berbeda pada media LBA dan TSA. Akan tetapi perubahan signifikan terlihat bahwa pertambahan waktu fermentasi menyebabkan semakin berkurangnya jumlah koloni mikroba. Hal ini terjadi pula pada kombucha teh hijau, bahwa semakin lama fermetasi semakin jumlah koloni yang didapatkan. Hasil berbeda didapatkan pada smapel kombucha dari teh oolong. Pada kombucha teh oolong, semakin lama waktu fermentasi maka semakin banyak koloni yang terisolasi. Dari dasar ini dapat diketahui waktu fermentasi optimum dari mikroba fermenter di dalam masing-masing sampel kombucha. Pada kombucha teh putih, teh hitam dan teh hijau, masa fermentasi sudah tidak dapat dutambah karena jumlah koloni mikroba sudah menurun. Beda halnya dengan kombucha teh ooloong, dengan hasil tersebut masa fermentasi amsih dapat ditambhkan untuk memaksimalkan hasil fermentasi.

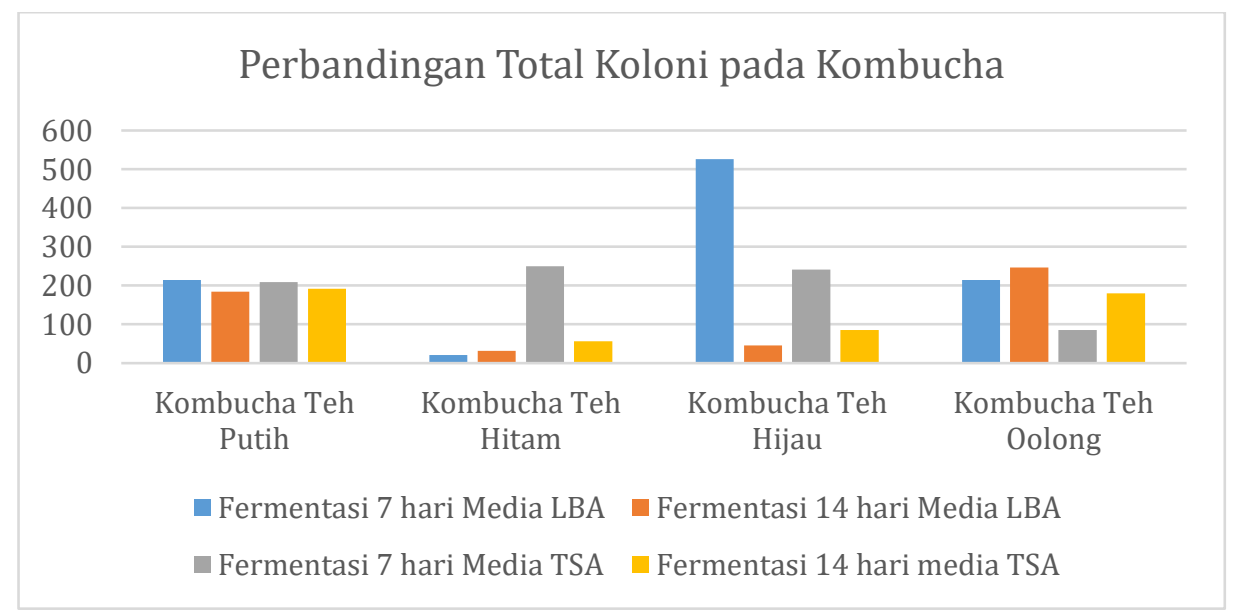

Gambar 3. Grafik Perbandingan Total Koloni Mikroba pada Media LBA dan TSA 


\section{Perhitungan Total Sel Mikroba}

Mikroba yang berperan dalam proses fermentasi kombucha terdiri atas dua kelompok besar yaitu kelompok bakteri dan khamir. Kedua kelompok mikroba ini melakukan pekerjaan yang simultan didalam proses fermentasi untuk menghasilkan kombucha. Bahkan menurut May, et al (2019), sistem fermetasi yang berlangsung di dalam kombucha dapat menjadi sistem model untuk mempelajari simbiosis dalam hal ini kooperattif dalam pkehidupan mikroba. Di dalam kombucha bakteri dan khamir hidup berdampingan dan saling mendukung satu sama lain. Dengan adanya kooperasi antara bakteri dan khmamir, sistem fermentasi kombucha dapat terhindar dari kompetitor oenyerangnya, seperti mold.

Pada bagian ini dilakukan pengamatan sel mikroba dan jumlah dari sel mikroba tersebut. Pada gambar 4 dapat terlihat bahwa sel khamir jauh lebih besar dibandingkan dengan sel bakteri. Selain itu, sel khamir ditandai dengan adanya bentuk khusus yang menandakan familynya, serta memperlihatkan proses reproduksi yang dialaminya yaitu pembentukan tunas (budding). Dengan dasar ini dilakukan perhitungan jumlah sel bakteri dan khamir secara terpisah.

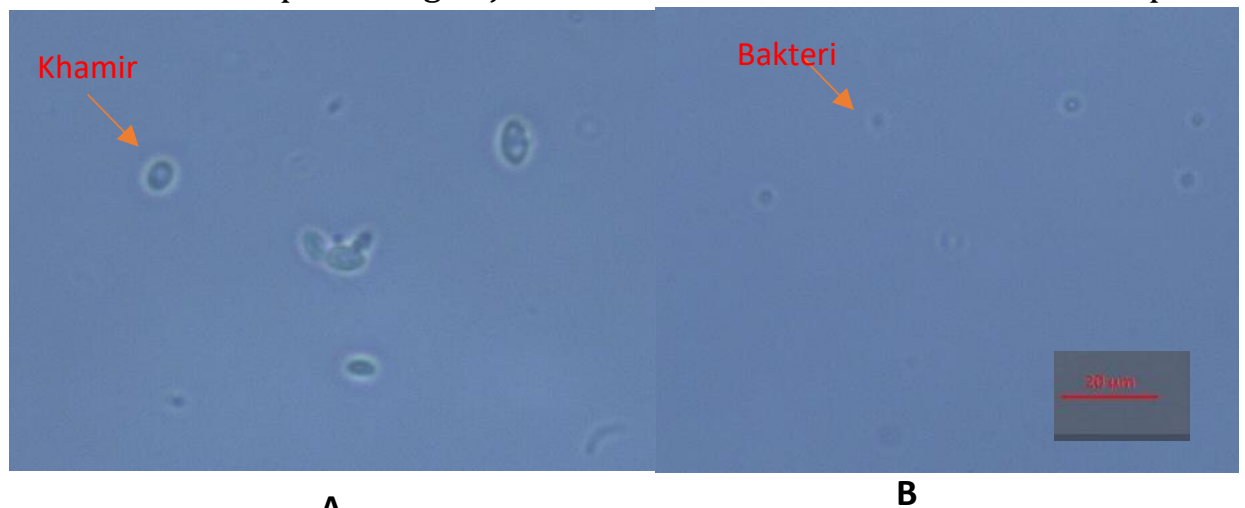

A

B

Gambar 4. A. Sel Khamir, B. Sel bakteri

Tabel 3. Perhitungan jumlah sel bakteri dan khamir pada kombucha fermentasi 7 hari

\begin{tabular}{|c|c|c|c|c|c|}
\hline No & Sampel & Parameter & Hasil uji & Satuan & Metode uji \\
\hline 1 & Teh putih & $\begin{array}{c}\text { Total Bakteri } \\
\text { Total Khamir }\end{array}$ & $\begin{array}{c}2,5 \times 10^{7} \\
5,1 \times 10^{6}\end{array}$ & Sel/mL & $\begin{array}{c}\text { Mikroskopis } \\
\text { (Haemacytometer) }\end{array}$ \\
\hline 2 & Teh hitam & $\begin{array}{c}\text { Total Bakteri } \\
\text { Total Khamir }\end{array}$ & $\begin{array}{l}2,5 \times 10^{7} \\
5,6 \times 10^{6}\end{array}$ & Sel/mL & $\begin{array}{c}\text { Mikroskopis } \\
\text { (Haemacytometer) }\end{array}$ \\
\hline \multirow{2}{*}{3} & Teh hijau & $\begin{array}{c}\text { Total Bakteri } \\
\text { Total Khamir }\end{array}$ & $\begin{array}{l}4,6 \times 10^{7} \\
1,2 \times 10^{7}\end{array}$ & Sel/mL & $\begin{array}{c}\text { Mikroskopis } \\
\text { (Haemacytometer) }\end{array}$ \\
\hline \multirow{2}{*}{4} & Teh oolong & $\begin{array}{c}\text { Total Bakteri } \\
\text { Total Khamir }\end{array}$ & $\begin{array}{l}1,1 \times 10^{7} \\
1,3 \times 10^{6}\end{array}$ & Sel/mL & $\begin{array}{c}\text { Mikroskopis } \\
\text { (Haemacytometer) }\end{array}$ \\
\hline
\end{tabular}

Tabel 4. Perhitungan jumlah sel bakteri dan khamir pada kombucha fermentasi 14 hari

\begin{tabular}{|c|c|c|c|c|c|}
\hline No & Sampel & Parameter & Hasil uji & Satuan & Metode uji \\
\hline 1 & Teh putih & $\begin{array}{c}\text { Total Bakteri } \\
\text { Total Khamir }\end{array}$ & $\begin{array}{l}2,3 \times 10^{7} \\
3,4 \times 10^{6}\end{array}$ & Sel/mL & $\begin{array}{c}\text { Mikroskopis } \\
\text { (Haemacytometer) }\end{array}$ \\
\hline 2 & Teh hitam & $\begin{array}{c}\text { Total Bakteri } \\
\text { Total Khamir }\end{array}$ & $\begin{array}{l}1,5 \times 10^{7} \\
1,6 \times 10^{6}\end{array}$ & Sel/mL & $\begin{array}{c}\text { Mikroskopis } \\
\text { (Haemacytometer) }\end{array}$ \\
\hline \multirow{2}{*}{3} & Teh hijau & $\begin{array}{c}\text { Total Bakteri } \\
\text { Total Khamir }\end{array}$ & $\begin{array}{l}8,8 \times 10^{7} \\
1,3 \times 10^{7}\end{array}$ & Sel/mL & $\begin{array}{c}\text { Mikroskopis } \\
\text { (Haemacytometer) }\end{array}$ \\
\hline \multirow{2}{*}{4} & Teh oolong & $\begin{array}{c}\text { Total Bakteri } \\
\text { Total Khamir }\end{array}$ & $\begin{array}{l}1,4 \times 10^{7} \\
3,2 \times 10^{6}\end{array}$ & Sel/mL & $\begin{array}{c}\text { Mikroskopis } \\
\text { (Haemacytometer) }\end{array}$ \\
\hline
\end{tabular}

Pada tabel diatas terlihat bahwa terjadi perubahan jumlah sel, baik bakteri maupun khamir. Pada sampel teh putih dan teh hitam, jumlah sel mengalami penurunan, sedangkan pada 
teh hijau dan teh oolong menglamai peningkatan. Peningkatan jumlah sel yang paling signifikan terlihat pada sampel teh hijau, meskipun hasil ini tidak sejalan pada jumlah koloni yang mana sampel teh hijau mengalami penurunan jumlah koloni. Hal ini semakin mempertegas bahwa jumlah koloni dan jumlah sel adalah dua hal yang berbeda.

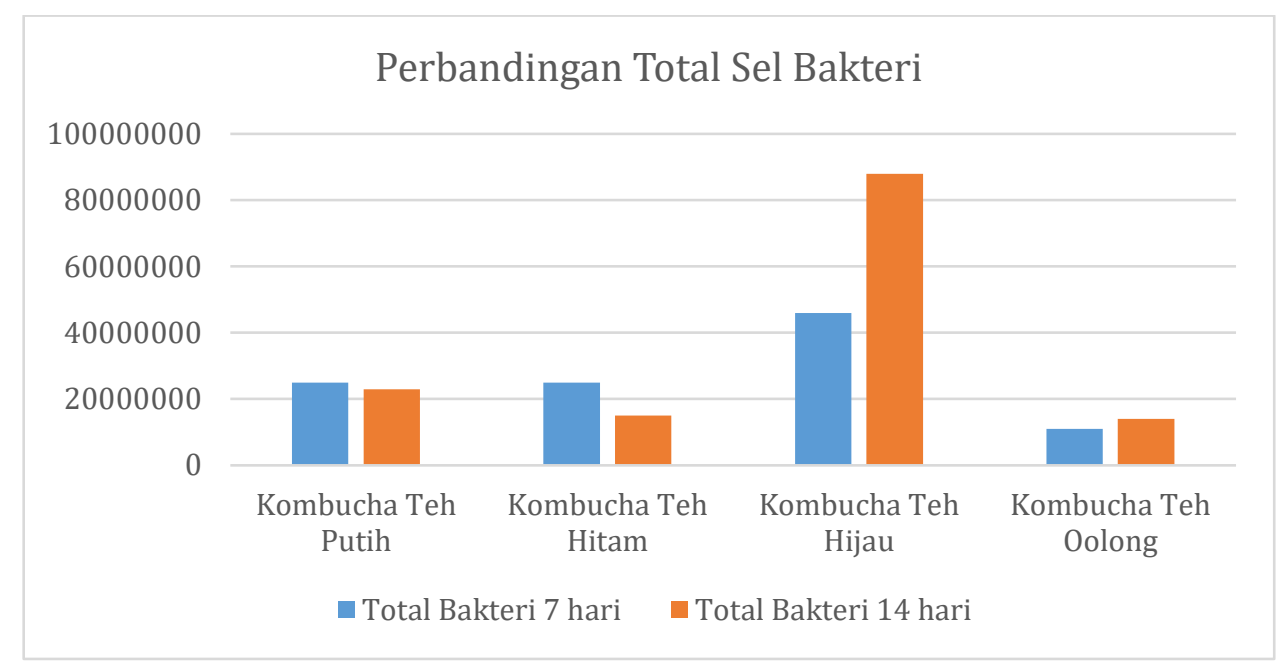

Gambar 5. Perbandingan Total Sel Bakteri

Pada grafik ini terlihat dinamika perubahan total sel bakteri. Disini dapat diamati bahwa pada kombucha teh putih dan kombucha teh hitam mengalami penurunan jumlah sel bakteri, sementara pada kombucha teh hijau dan teh oolong mengalami peningkatan jumlah sel bakteri. Hal yang sama teramati pada pengamatan total sel khamir (gambar 6). Pada kombucha teh putih dan kombucha teh hitam terjadi oenurunan jumlah sel khamir seiring pertambahan lama waktu fermentasi. Sementara pada kombucha teh hijau dan kombucha teh oolong mengalami pertambahan jumlah sel khamir seiring pertambahan waktu fermentasi.

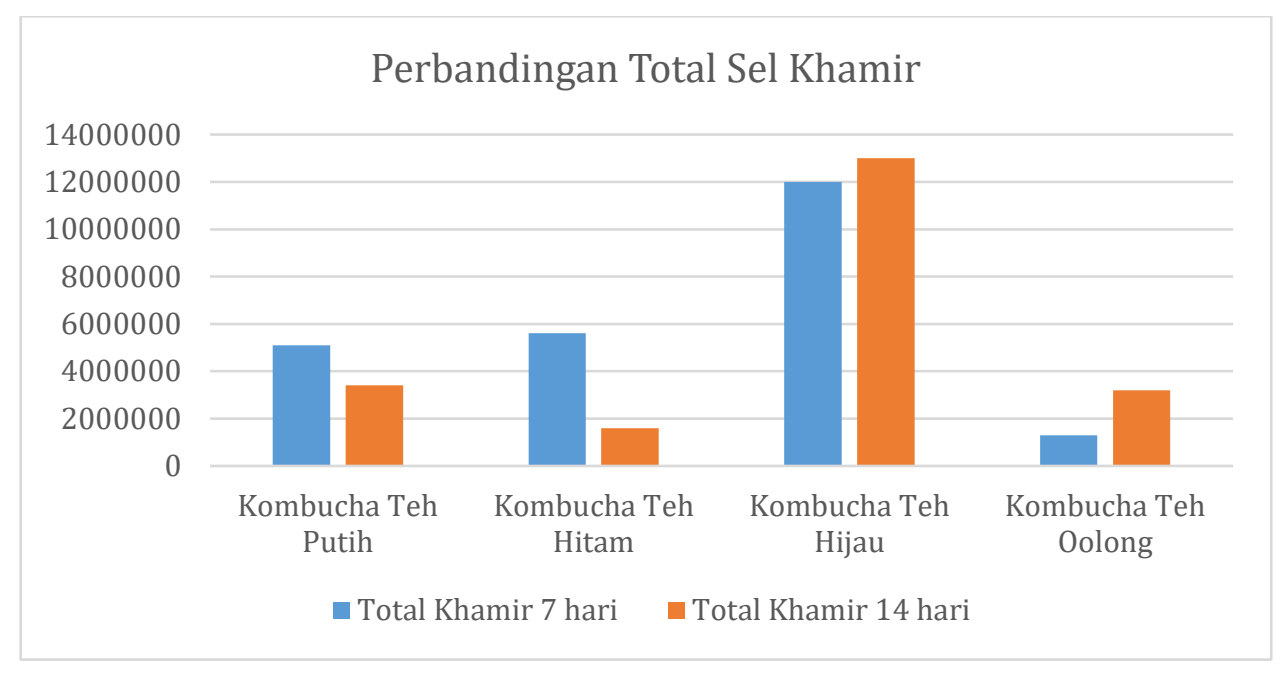

\section{Gambar 6. Perbandingan Total sel Khamir}

Menurut Jayabalan, et al (2014), setiap sistem fermentasi kombucha akan memiliki jenis bakteri khamir yang berbeda, begitu pula dengan jumlah selnya. Bahkan waktu optimum untuk masa fermentasipu berbeda, banyak hal yang turut mendukung proses fermentasi tersebut seperti cahaya, suhu, kelembaban dan semacamnya. Berbagai penelitian menunjukkan bahwa 
bahkan untuk jenis teh yang sama pun ketika dibuat pada tempat yang berbeda dengan kondisi lingkungan yang berbeda akan menghasilkan kombucha dengan rasa yang berbeda. Hal ini tentu terkait dengan jenis dan jumlah sel bakteri dan khamir yang berada di dalam sistem fermentasi. Penelitian Jarrel, et al (2000) menemukan bahwa jumlah koloni bakteri meningkat untuk sampel kombucha dengan sumber kultur "Fritz" dan "Olinka". Sementara ketika mencobakan pembuatan kombucha tanpa penambahan strater, ditemukan hasil bahwa koloni bakteri tersebut mengalami penurunan.

Bakteri dan khamir yang berada di dalam sistem fermentasi kombucha berperan sangat penting dalam proses fermntasi kombucha tersebut. Simbiosis yang dilakukan oleh bakteri dan khamir di dalam fermentasi kombucha menghasilkan minuman kombucha dengan jumlah dan kadar senyawa kimia yang meningkat. Bukan hanya itu, konsorsia bakteri dan khamir memainkan simbiosis yang sangat kuat sehingga dapat melindungi sistem fermentasi kombucha dan menghambat pertumbuhan bakteri yang berpotensi mengkontaminasi proses fermentasi (Soto, et al, 2018).

\section{Kesimpulan}

Kombucha merupakan minuman hasil fermentasi dari cairan teh dan gula. Berbagai daun kaya fenol dapat menjadi substrat untuk pembuatan kombucha, seperti daun teh, daun sirih, daun kopi, dam semacamnya. Fermentasi kombucha dilakukan oleh konsorsia bakteri dan khamir yang gabungannya disebut sebagai SCOBY (Symbiotic Culture of Bacteria and Yeast). Bakteri dan yeast di dalam sistem fermentasi melakukan pekerjaan yang simultan dan saling mendukung bahkan disebut sebagai simbiosis yang sangat kuat. Bahkan simbiosis konsorsia bakteri dan khamir itu sendiri dapat menjadi pertahanan yang kuat dari sistem fermentasi untuk menghambat pertumbuhan mikroba pengganggu atau pengkontaminasi. Dari proses fermentasi tersebut, dihasilkan minuman kombucha dengan jumlah dan kadar senaywa kimia yang meningkat dibandingkan pada substrat awalnya. Dengan hal tersebut, kombucha disebut sebagai minuman yang dapat meningkatkan kesehatan konsumennya, dapat meningkatkan metabolisme, bahkan menyembuhkan berbagai penyakit. Selain kondisi lingkungan, salah satu hal penting yang mendukung proses fermentasi adalah lama waktu fermentasi dan jumlah dari bakteri dan khamir. Dari penelitian ini diketahui bahwa lama waktu fermentasi optimum untuk setiap smapel substrat berbeda-beda, hal ini terkait kandungan senyawa awal yang dimiliki oleh substrat tersebut. Selain itu disini dapat pula dikonfrimasi bahwa peningkatan dan penurunan jumlah koloni maupun sel bakteri dan khamir tidak bersifat pasti. Keadaan lingkungan meberikan efek yang kuat pada hal tersebut.

\section{Acknowledgement}

Peneliti mengucapkan terima kasih kepada DRPM Kemdikbud karena telah mendanai penelitian ini.

\section{Referensi}

Crum., Hannah \& Alex LaGory. (2016). The Big Book of Kombucha: Brewing, Flavoring, and Enjoying the Health Benefits of Fermented Tea. USA. Storey Publishing.

Essawet, N.A., et al., (2015). Pholyphenols and Antioxidant Activities of Kombucha Beverage Ennriched with Coffeberry Extract. Chem. Ind. Chem. Eng. Q. 1(3), 399-409.

Jayabalan, R., Radomir V. Malba`sa, Eva S. Lon`car, Jasmina S. Vitas, and Muthuswamy Sathishkumar. (2014). A Review on Kombucha Tea- Microbiology, Composition, Fermentation, Beneficial Effects, Toxicity, and Tea Fungus. Comprehensive Reviews in Food Science and Food Safety.13. 
J. Jarrell, T. Cal, and J. W. Bennett, (2000) "The Kombucha consortia of yeasts and bacteria," Mycologist. 14, (4), 66-170. doi: 10.1016/S0269-915X(00)80034- 8. 4. S. A.

Lelita, D. I., Rohadi \& A. S. Putri. (2018). Sifat Antioksidatif Ekstrat The (Camellia sinensis Linn.) Jnis Teh Hijau, Teh Hitam, Teh Oolong dan Teh Putih dengan Pengeringan Beku (Freeze Drying). Jurusan Teknik Hasil Pertanian, Fakultas Teknologi Pertanian, Universitas Semarang.

May, A., et al., (2019). KOmbucha: A Novel Model System for Cooperation and Conflict in a Complex Multi-Species Microbial System. PerrJ. Doi : 10.7717.peerj.7565.

Nainggolan, J. (2009). Kajian Pertumbuhan Bakteri Acetobacter sp. dalam Kombucha Rosela Merah (Hibiscus sabdariffa) pada kadar gula dan Lama Fermentasi yang Berbeda. Tesis. Pascasarjana Universitas Sumatera Utara, Medan.

Rohdiana, D., (2015). Teh: Proses, karakteristik dan komponen fungsionalnya. Foodreveiew Indonesia. 10. (8), 34-37.

S. Chakravorty, S. Bhattacharya, A. Chatzinotas, W. Chakraborty, D. Bhattacharya, and R. Gachhui. (2016). Kombucha tea fermentation: Microbial and biochemical dynamics," Int. J. Food Microbiol. 220, 63-72. doi: 10.1016/j.ijfoodmicro.2015.12.015. 3.

Sreeramulu, G., Zhu, Y., Knol, W., (2000). Kombucha Fermentation and Its Antimicrobial Activity. J. Agric. Food Chem. 48, 2589-2594. https://doi.org/10.1021/if991333m

Suhardini, Prasis N., dan Elok Zubaidah. 2016. Studi Aktivitas Antioksidan Kombucha Dari Berbagai Jenis Daun Selama Fermentasi. Jurnal Pangan dan Agroindustri. 4 (1), 221-229.

Towaha, J. (2013). Kandungan senyawa kimia pada daun teh (Camellia inensis). Warta penelitian dan pengembangan tanaman industri. 19 (3).

Tran, T., et al., (2020). Microbial Dynamics between Yasets and Acetic Acid Bacteria in Kombucha :Impacts on the Chemical Composition of the Beverage. Foods. 9. Doi: 10.3390 /foods 9070963 .

Villarreal-Soto, S. Beaufort, J. Bouajila, J.-P. Souchard, and P. Taillandier. (2018) “Understanding Kombucha Tea Fermentation: A Review," J. Food Sci. 83 (3), 580-588.

\begin{tabular}{|l|l|}
\hline Azrini Khaerah & $\begin{array}{l}\text { Universitas Muhammadiyah Bulukumba } \\
\text { E-mail: azrini.khaerah@gmail.com }\end{array}$ \\
\hline Halijah & $\begin{array}{l}\text { Universitas Muhammadiyah Bulukumba } \\
\text { E-mail: halijaija43@gmail.com }\end{array}$ \\
\hline Nurhilmi Nawir & $\begin{array}{l}\text { Universitas Muhammadiyah Bulukumba } \\
\text { E-mail: } \underline{\text { nurhilmi015@gmail.com }}\end{array}$ \\
\hline
\end{tabular}

